\title{
Applications and Practice of Blended Teaching Mode Based on Cloud Platform in Higher Vocational Colleges
}

\author{
Chengjie Zhang ${ }^{1, \text { a }}$ \\ ${ }^{1}$ Department of Information Engineering, Weihai Vocational College, Weihai, Shandong Province, \\ China \\ a382014179@qq.com
}

Keywords: Blended Learning, Cloud Platform, Face-To-Face, Online.

\begin{abstract}
In order to improve the classroom efficiency and teaching quality in higher vocational colleges, this paper adopted several methodologies, such as the methods of investigation, literature research and empirical research to analyze the key problems of blended teaching mode design in higher vocational colleges. It also proposed proper blended teaching modes in higher vocational colleges and present the effective implementation of mode through a teaching unit with an intention of providing suggestions to the reform of blended teaching mode in higher vocational colleges.
\end{abstract}

\section{Introduction}

With the rapid development of the Internet, information technology has greatly influenced people's learning. In the late 80 s of the 20th century, E-learning has become a hit. People want to use E-learning to replace the traditional classroom teaching. However, after a period of practice, people have found that E-Learning cannot completely replace the traditional classroom teaching. The traditional classroom teaching has great advantages in knowledge teaching, sociality and interactivity. The teachers' dominant position in teaching cannot be replaced. People have deep exploration into E-learning learning and put forward the concept of blended learning mode. Professor Ke-kang He defines blended learning mode as "the integration of the advantages of traditional learning and E-Learning (digital learning or network learning)" [1]. The deeper understanding is a mode in which the main subject is the students and the director is the teachers. The teachers' and the students' roles are changing. The teachers play their role in guiding, enlightening, supervising and controlling during the teaching process. The students can performance their initiative, enthusiasm and creativity in the environment constructed by their teachers and achieve the best learning.

With the deepening of the construction of digital universities and colleges in our country, higher vocational colleges are also actively carrying out teaching reform and introduce a series of advanced educational resources and means, such as multimedia courseware, excellent courses, resource library and electronic whiteboard. However, most of them adopt the traditional teaching mode. Thus, the students are not interested in learning and gain poor results. In recent years, the rise of E-learning online learning has not achieved better results due to the students' poor learning basic and their poor learning habits, self-learning ability. It is the key of changing the mode of personnel training for the higher vocational colleges to escape from the shackles of the traditional education mode and realize the reform of the blended teaching mode combined with the online and classroom teaching.

\section{Several Key Problems to the Blended Teaching Design of Higher Vocational Colleges}

Blended learning is a kind of learning method to promote the optimization of learning results. In order to ensure the effective implementation of blended teaching, it is necessary for teachers of higher vocational colleges to become the directors who direct the students' learning activity from the communicators who exchange information. The teachers should comprehensively control the teaching objectives, teaching design, teaching implementation, teaching evaluation and so on. Based on the vocational students' learning characteristics, this paper focuses on the following issues in the blended mode design. 
To deal with the proportion of classroom teaching and online learning. Classroom teaching and online learning have their own advantages and disadvantages, as well as the proper adaptation field. In the blended learning design, it requires a balance between the traditional classroom learning and online learning which is in accordance with the characteristics of the students. Too much online learning is not conducive to the systematic knowledge learning. The traditional classroom learning will ignore the advantages of online learning. Because of the students' poor learning initiative and their dislike of heavy after-school homework, it is necessary to make the students get more knowledge within the least time without any learning burden. It is suggested that the proportion of the online learning to the classroom teaching should be 1 to 2 .

The choice of teaching content and reasonable cut. The key to blended teaching is the perfect combination of online and offline learning, which requires that the teachers should classify the teaching content according to the level of knowledge, difficulty and other factors and determine what content can be learnt online and what content can be learnt in the classroom. The teachers should guide the students to master knowledge. Modern cognitive psychology classifies the knowledge into three types, declarative knowledge, procedural knowledge and strategic knowledge. Declarative knowledge is about what knowledge is. Procedural knowledge is mainly used to solve what to do and how to do. Strategic knowledge is the knowledge of how to learn and how to think. [2] The students in higher vocational colleges have lower admission scores compared to those in undergraduate institutions. Because of their relatively weak learning base and poor self-learning ability, it would be easier for them to understand declarative knowledge through E-learning while learn procedural knowledge and strategic knowledge in the classroom. The teachers should design the teaching tasks according to the teaching content and guide the students to study and explore, so as to improve the teaching efficiency.

Design of teaching activities. The teachers' central task in blended instructional design is to design the teaching activities. The students in higher vocational colleges have not developed good learning habits in high school. They can only concentrate for a short time, usually about 5 to 10 minutes. Therefore, the online learning could be composed by different knowledge points, in the form of the video with 5 to 10 minutes. The higher vocational education is to promote the students' professional ability and impart knowledge of the working process. Thus, the classroom teaching proposes the task-driven or problem-driven teaching methods. After the analysis and integration of the actual work tasks, we can determine the typical work based on learning task. Through the task-driven, the teachers can guide the students to truly integrate into the working environment and enhance their interest in learning to ensure the effective implementation of learning objectives.

To provide the effective learning support and supervision. The vocational students' self-binding ability is generally poor. Thus, the teachers' guidance and supervision is particularly important to help the students be subjective initiative in the implementation of the blended teaching mode of E-learning and positively participate in the teachers' well-designed teaching environment and teaching activities. In the online learning process, the teachers should use E-learning platform, so that the students can communicate with the other classmates and the teachers can timely communicate with the students and solve their problems encountered in learning. At the same time, the teachers can monitor students' learning progress and status at any time. In the classroom teaching, being the organizer of the teaching activities, the teachers should design the teaching task, actively think and find out the problems, provide the necessary advice and guidance to help the students solve the problems and improve the students' professional skills.

To establish a diversified evaluation system. In higher vocational education, the teachers' another task is to establish a scientific evaluation system, using the online and offline blended evaluation. In this case, the teacher evaluation and the student evaluation can be organically combined to make the evaluation be process-oriented instead of result-oriented. Therefore, the teachers can timely give the students the feedback and scientific evaluation of their learning process and achieve the effective monitoring of the entire learning process. 


\section{Design and Implementation of Blended Teaching Mode in Higher Vocational Colleges}

Design of blended teaching mode in higher vocational colleges. According to the goal of cultivating high-skilled talents in higher vocational colleges and the students' characteristics, this paper designs a design mode of blended learning in higher vocational colleges in order to solve some key problems in the blended teaching design of higher vocational colleges, shown in Figure 1. Blended learning includes online learning and offline learning. The teachers focus on the teaching objectives and the teaching content, analyze the students' characteristics and design the online and offline teaching. The online learning is based on the students' self-learning. In the cloud platform, the teachers give the self-learning tasks to the students and upload learning resources. The students finish their online learning, discussions and complete their learning task. Classroom teaching is teacher-oriented, using the task-driven form. The effective integration of online learning and classroom teaching will improve the learning efficiency and achieve the teaching objectives.

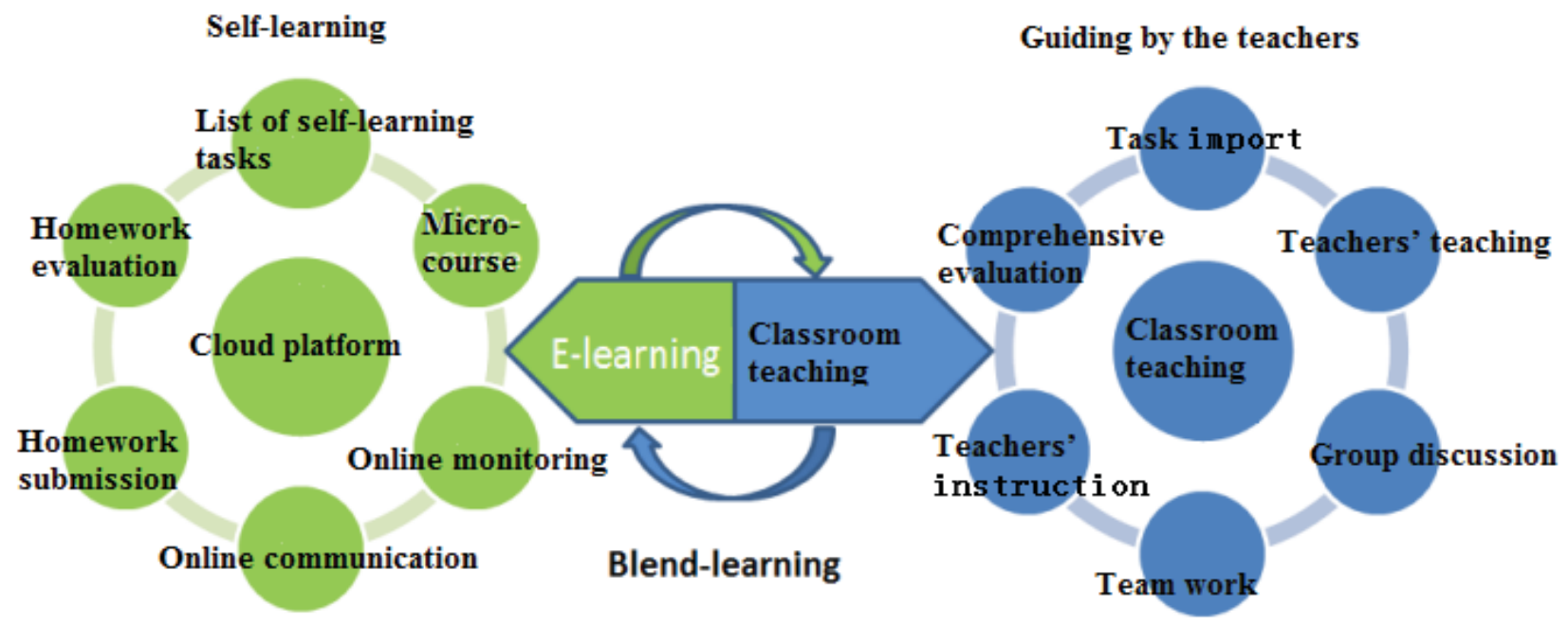

Fig 1. Blended learning mode in higher vocational colleges

Implementation of blended teaching mode in higher vocational colleges. A teaching unit of Java Language Programming, array, is taken as an example, showing blended learning teaching design. The course adopts the blended teaching mode, including the online micro-class learning and the traditional teaching. In order to improve the supervision and efficiency of teaching, it also adopts mobile teaching assistant APP which is based on the cloud platform which is developed by Beijing Zhiqilan Ink Information Technology Co., Ltd. This APP helps to create a mobile course and upload it. Therefore, the students can use the mobile terminal equipment to study at any time and in any place. The teachers can also monitor the students' learning at any time and communicate with them, so as to ensure the effectiveness of the teaching.

Course analysis. In the unit of array, the teaching goal is to make the students master the definition of array, as well as its construction and usage, and help the students to solve practical problems with array. The learning of array is divided into three class hours. Before the class, the teachers reasonably divide the teaching content according to the students' awareness level and adjust the class hour. The original classroom teaching has become one online class hour and two classroom teaching hours. The teaching objectives have been achieved through the combination of online and offline learning. The specific content is as shown in Table 1. 
Table 1. The Arrangement of studing Content

\begin{tabular}{|c|c|c|c|}
\hline $\begin{array}{l}\text { Numb } \\
\text { er }\end{array}$ & Earning Content & Learning style & Learning objectives \\
\hline 1 & What is an array & e-learning & $\begin{array}{l}\text { Understanding the concept } \\
\text { of arrays }\end{array}$ \\
\hline 2 & Array definition & e-learning & $\begin{array}{l}\text { Learn how to use Java } \\
\text { language to define arrays }\end{array}$ \\
\hline 3 & Array access & e-learning & $\begin{array}{l}\text { Master array element access } \\
\text { method }\end{array}$ \\
\hline 4 & $\begin{array}{l}\text { Application of array(sort student } \\
\text { score) }\end{array}$ & face-to-face & $\begin{array}{l}\text { Solving practical problems } \\
\text { with array knowledge }\end{array}$ \\
\hline 5 & $\begin{array}{l}\text { Extension of knowledge (Array as } \\
\text { function parameter, } \\
\text { Two-dimensional array and } \\
\text { Multidimensional array) }\end{array}$ & face-to-face & $\begin{array}{l}\text { Mastering advanced } \\
\text { applications of arrays }\end{array}$ \\
\hline
\end{tabular}

Implementation of online learning. In order to ensure the quality of online learning, the teachers need to prepare the teaching resources before class, decompose the knowledge and record the micro-class videos. They also design the self-learning tasks according to the teaching goal, make clear the students' online learning content, goals and tasks. By using the cloud-based mobile teaching assistant APP developed by Beijing Zhiqilan Ink Information Technology Co., Ltd., the teachers create a mobile course and invite the students to join the course. The teachers upload the self-learning list, learning resources, including videos, courseware, etc. With the cloud platform, the students can use mobile terminal equipment to learn at any time in anyplace. The students use their mobile phones or computers to download and watch the learning resources and finish the learning tasks through the self-study. They can record the completion of tasks and problems encountered and then submitted in the form of homework. With the usage of the mobile-side APP, the teachers can monitor the learning situation of the students to view their download and learning resources, interact with the students, view the students' homework, sum up the problems the students encountered and give them answers in the classroom, so that they can improve the effectiveness and performance of teaching.

Implementation of offline learning. The focus of higher vocational teaching is to cultivate the students' professional skills. Therefore, the teachers should be combined with theoretical practice in practical teaching. Therefore, the task-driven form is adopted in the classroom teaching. It creates the learning situation according to the students' knowledge and introduces the tasks to order the students' learning results. The teachers explain the task requirements and the difficult knowledge required to solve the tasks. The students are divided into different learning groups, generally 3 to 5 each group. While discussing the online and offline knowledge, they can actively explore the activities and experience learning with fun and cultivate their curiosity. The teachers can gradually increase the difficulty of the tasks to complete the scores of the students from different classes and enlarge their knowledge.

Teaching evaluation. Teaching evaluation adopts the method of blended evaluation, dividing into online learning and offline learning. The evaluation of online learning is given by the teachers according to the participation degree of the students' autonomous study and their homework submission. The evaluation of offline learning is based on the students' mutual evaluation, the groups' mutual evaluation and the teachers' evaluation. Therefore, the teachers can conduct a comprehensive evaluation of the students' learning.

Analysis of teaching effect. By adopting the comparison method, the comparison is conducted between the class with the blended teaching mode and the class with the traditional classroom teaching. The results show that the students' scores with the blended teaching are significantly better than the common class. The comparison results are shown in Table 2. 
Table 2. comparison of the performance between the blended learning experiment class and the common class

\begin{tabular}{|c|c|c|c|c|c|c|c|}
\hline Class & $\begin{array}{l}\text { Avera } \\
\text { ge }\end{array}$ & $\begin{array}{l}\text { Excellent } \\
\text { more) }\end{array}$ & Rate $(85$ & points & $\begin{array}{l}\text { Good } \\
\text { rate }\end{array}$ & $\begin{array}{l}\text { Failure } \\
\text { points } \\
\text { below) }\end{array}$ & Rate(60 \\
\hline $\begin{array}{l}\text { Experiment } \\
\text { class }\end{array}$ & 83 & $40 \%$ & & & $58 \%$ & $2 \%$ & \\
\hline Common class & 75 & $25 \%$ & & & 69 & $6 \%$ & \\
\hline
\end{tabular}

\section{Conclusions}

This paper analyzed the characteristics of the students in higher vocational colleges, proposed some key problems occurred in the design of blended teaching mode in higher vocational colleges and put forward the construction mode of the blended teaching mode which is suitable for the training objectives and curriculum characteristics of higher vocational education. The practical examples show the effectiveness of the blended teaching mode in higher vocational colleges, which contributes to the vocational colleges to provide suggestions for the reform of the blended teaching mode.

\section{References}

[1] Ke-kang He. New Development of Educational Technology Theory from the Perspective of Blend-learning (Volume One). E-education Research, 2004.

[2] Jian Song. Basic Knowledge of Modern Science and Technology [M]. Beijing: Science Press, 2001.

[3] Ke-kang He. New Development of Educational Technology Theory from the Perspective of Blend-learning (Volume Two). E-education Research, 2004.

[4] Jia-hou Li. On the Definition and Translation of Blended Learning [J]. www.feast.net/jiahou/archives/OG18.htm1, 2004.

[5] Gen-fu Yang. Research on the Sustainable Use and Performance Factors of Network Teaching Platform in Blended Learning Mode. E-education Research, 2015.

[6] Jing Wang \& Wei-dong Chen. Review the Essence of Blended Learning from Embodied Cognition Perspective [J]. Journal of Distance Education, 2016.

[7] Rick J-Valdez, Blended Learning Maximizing the Impact of an Integrated Solution[M]. http://www.sanantonio-astd.Org/EIrng Docs/blended learning.pdf 